\title{
Sustained swimming mitigates stress in juvenile Brycon amazonicus reared in high stocking densities
}

\author{
Gustavo Alberto Arbeláez-Rojas ${ }^{(1)}$, Gilberto Moraes $^{(1)}$, Cleujosí da Silva Nunes ${ }^{(1)}$ and Fernando Fabrizzi(1)
}

(1)Universidade Federal de São Carlos, Departamento de Genética e Evolução, Rodovia Washington Luiz, Km 235, CEP 13565-905 São Carlos, SP, Brazil. E-mail: matamba2@yahoo.com.br, gibaufscar@gmail.com, cleujosi@yahoo.com.br, ferfabrizzi@hotmail.com

\begin{abstract}
The objective of this work was to evaluate the effect of stocking density associated with the swimming exercise on the stress responses of Brycon amazonicus. During 70 days, fish were subjected to three stocking densities: LD, low density of 88 fish per cubic meter; ID, intermediary density of 176 fish per cubic meter; and HD, high density of 353 fish per cubic meter. These densities were combined with static water (non-exercised group) or moderate-speed water (exercised group). Chronic stress was observed in HD, and plasma cortisol and glucose increased with the stocking densities. In HD, levels of plasma cortisol were significantly lower in exercised fish $\left(135 \mathrm{ng} \mathrm{mL}^{-1}\right)$ than in non-exercised ones $\left(153 \mathrm{ng} \mathrm{mL}^{-1}\right)$. The greatest hepatic glycogen bulks occurred in fish kept in ID and sustained swimming. Hepatic free amino acids (FAA) increased with the stocking density, particularly in non-exercised fish. The contents of FAA in the liver and of free fatty acids (FFA) in the liver and muscle were mobilized to meet the metabolic demands imposed by exercise and stocking density. The hematological parameters remained stable. The results show that Brycon amazonicus is more resistant to stress when subjected to sustained swimming and high stocking density than to static water.
\end{abstract}

Index terms: animal welfare, intensive fish farming, metabolic responses, physical exercise.

\section{Natação sustentada atenua o estresse em juvenis de Brycon amazonicus criados em alta densidade de estocagem}

\begin{abstract}
Resumo - O objetivo deste trabalho foi avaliar o efeito da densidade de estocagem associada ao exercício de natação nas respostas ao estresse de matrinxã (Brycon amazonicus). Durante 70 dias, os peixes foram submetidos a três densidades de estocagem: $\mathrm{BD}$, baixa densidade de 88 peixes por metro cúbico; $\mathrm{DI}$, densidade intermediária de 176 peixes por metro cúbico; e $\mathrm{AD}$, alta densidade de 353 peixes por metro cúbico. Estas densidades foram combinadas com água parada (grupo não exercitado) ou com água em velocidade moderada (grupo exercitado). $\mathrm{O}$ estresse crônico foi observado em $\mathrm{AD}$, e o cortisol e a glicose plasmática aumentaram com a densidade de estocagem. Em AD, os níveis plasmáticos de cortisol foram significativamente menores nos peixes exercitados (135 $\left.\mathrm{ng} \mathrm{mL}^{-1}\right)$ do que nos não exercitados $\left(153 \mathrm{ng} \mathrm{mL}^{-1}\right)$. Os maiores acúmulos de glicogênio hepático ocorreram em peixes mantidos em DI e em natação sustentada. Os aminoácidos livres (AAL) hepáticos aumentaram com a densidade de estocagem, particularmente nos peixes não exercitados. As reservas de AAL hepáticos e de ácidos graxos livres hepáticos e musculares foram mobilizados para atender às demandas metabólicas impostas pelo exercício e pela densidade de estocagem. Os parâmetros hematológicos mantiveram-se estáveis. Os resultados são indicativos de que o matrinxã é mais resistente ao estresse quando submetido à natação sustentada e à alta densidade de estocagem que à água parada.
\end{abstract}

Termos para indexação: bem-estar animal, piscicultura intensiva, respostas metabólicas, exercício físico.

\section{Introduction}

Aquaculture is growing at a rate of $5.8 \%$ a year as consequence of a series of combined factors, such as human population growth, rising incomes, and urbanization, which require high-quality healthy products (FAO, 2016). In order to sustain or enhance this growth, a high-tech aquaculture is being adopted, with the development of oxygen generators, automatic recirculation systems, high quality food, and aquaculture systems that support high fish densities, among others (Badiola et al., 2012). However, to reach high profits, fish farmers tend to overstock, ignoring the species demands, which increases the competition for space and contributes to environmental deterioration. High stocking rates may cause environmental impacts, 
reduced water quality, and the increase of toxicants as ammonia (Björnsson \& Ólafsdóttir, 2006). These factors impair fish growth, health, and hematological parameters, increasing pathological conditions and leading to their death (Fazio et al., 2014).

If the morphological and behavioral signs of overcrowding (Ashley, 2007), which indicate abnormal conditions in the rearing systems, are not detected in time, there may be a significant increase in production costs. For fish, the permanency of these conditions can result in chronic stress, leading to a greater energy demand to maintain homeostasis (Larsen et al., 2012). The most common approach to mitigate the stress caused by high stocking densities is using conditioned feed. However, exercising fish to overcome crowding stress is currently being studied, aiming to improve the outcomes of fish farming.

Exercise has been shown to promote changes in fish growth, metabolism, and overall welfare (ArbeláezRojas \& Moraes, 2010; McKenzie et al., 2012). It has been reported that cold-water fish subjected to exercise are more resistant to disease by robustness or fitness than non-exercised ones (Davison \& Herbert, 2013). Furthermore, exercise reduces the time required to return to homeostasis after the handling and crowding stresses (Veiseth et al., 2006). For salmonids, exercise decreases blood levels of catecholamines, cortisol, and glucose (Davison \& Herbert, 2013), whereas, for trout, exercise at low water speeds is slightly beneficial for recovery after acute stress, but not when the source is crowding (McKenzie et al., 2012). This shows the need to better evaluate the practice of sustained swimming to enhance the capacity of fishes in coping with stress from high stocking densities.

In South America, the Neotropical freshwater fish Brycon amazonicus is a promising species for fish culture (Cruz-Casallas et al., 2011). Coming from the Amazon, Orinoco, and Tocantins-Araguaia River basins, this species has spread out over the Southeast region of Brazil due to its high growth rate, good performance, and exquisite flesh (Arbeláez-Rojas \& Moraes, 2010; Cruz-Casallas et al., 2011). It is also tolerant to transport, handling, and crowding (Abreu et al., 2008). Owing to its rheophilic habit, the species is able to swim for long distances to reproduce, besides being streamlined and fusiform, which has motivated its use in trials on the performance of fish subjected to sustained swimming (Arbeláez-Rojas \& Moraes,
2010). Therefore, to know and to optimize the stocking density of the species may be a crucial factor to plan the productivity and cost-effectiveness of intensive fish farms.

The objective of this work was to evaluate the effect of stocking density associated with the swimming exercise on the stress responses of B. amazonicus.

\section{Materials and Methods}

The experiment was conducted in the laboratory of adaptive biochemistry of fish of the Department of Genetics and Evolution of Universidade Federal de São Carlos, located in the municipality of São Carlos, in the state of São Paulo, Brazil.

Brycon amazonicus fingerlings were acquired from a commercial fish farm, located in the municipality of Mococa, also in the state of São Paulo, Brazil. The fish were transferred to the laboratory and held for over three weeks in 2,000 L tanks, in an aerated and thermostated flow-through water system, with mechanic and biological filters. Fish were kept under a natural 12-hour light:12-hour dark photoperiod and fed with $36 \%$ crude protein $(2-4 \mathrm{~mm}$ commercial pellets) until acclimated to the new conditions. After this period, 210 fish $(12.33 \pm 0.54 \mathrm{~cm}$ and $18.44 \pm 0.12 \mathrm{~g})$ were classified and randomly distributed in circular 250-L fiberglass tanks with $170 \mathrm{~L}$ of net water volume, as detailed below.

Water parameters were periodically checked during the trial, and the average values were maintained within the ideal range for most Neotropical freshwater fishes: $\quad 27.5 \pm 0.9^{\circ} \mathrm{C}, \quad 5.1 \pm 0.07 \quad \mathrm{mg}^{-1}$ dissolved oxygen, $\mathrm{pH} 7.1 \pm 0.8,0.03 \pm 0.02 \mathrm{mg} \mathrm{L}^{-1}$ ammonia, and $64.6 \pm 4.8 \mu \mathrm{S} \mathrm{cm}^{-1}$ conductivity.

The experiments were performed in a $3 \times 2$ factorial arrangement, with three fish densities and two exercise patterns, totalizing six treatments distributed into six tanks. The replicates consisted of ten fish sampled per tank at the end of the experimental period. Three fish densities were tested: LD, low density; ID, intermediary density; and HD, high density, corresponding to 15,30 , and 60 fish per tank or to 88, 176, and 353 fish per cubic meter, respectively. Each density was evaluated in two conditions: exercise and non-exercise. In the exercised groups, fish were stimulated to swim at a moderate speed of 1.0 body length per second. The water speed was generated by a $3 / 4$ HP pump as in Arbeláez-Rojas \& 
Moraes (2010). In the non-exercised groups (control), fish were left in static water. Except for water speed, all environmental conditions were rigorously maintained in all tanks. Throughout the trials, the fish were kept under natural photoperiod of nearly 12:12 hours for 70 days and were fed by hand with extruded 3-4-mm commercial pellets (32\% crude protein, $13 \%$ moisture, $4 \%$ crude lipid, $14 \%$ ash, $6 \%$ crude fiber, $3 \%$ calcium, and $0.5 \%$ phosphorus), thrice a day to satiety.

At the end of the experimental period, feeding was discontinued and the fish were starved for 24 hours. Ten fish per tank were randomly netted and anesthetized with $40 \mathrm{mg} \mathrm{L}^{-1}$ eugenol. The size and weight of each fish were measured right away. Blood samples were withdrawn from the caudal vein in heparinized syringes (5.000 UI heparin), and 1.0-mL blood aliquots were separated in 2.0-mL Eppendorf tubes for hematological determinations. Plasma was separated by centrifugation at $5,000 \mathrm{~g}$ for $5 \mathrm{~min}$, at $5^{\circ} \mathrm{C}$, in a Mikro 200 centrifuge (Hettich Lab Technology North America, Beverly, MA, USA). Afterwards, fish were killed by cervical separation, and their liver, white muscle, and red muscle were rinsed with $0.9 \%$ cold saline and excised on a cold Petri dish. The livers were quickly weighed to determine the hepatosomatic index (HSI) and the condition factor (K). Then, liver and muscle samples were frozen using liquid nitrogen and kept at $-80^{\circ} \mathrm{C}$ for posterior metabolite analyses. The HSI and $\mathrm{K}$ were determined as follow: $\mathrm{HSI}=$ (liver weight/total weight) $\times 100$ and $\mathrm{K}=$ (total weight/total length $\left.{ }^{3}\right) \times 100$.

Hematocrit values were evaluated with a microhematocrit centrifuge; the content of hemoglobin, in $\mathrm{g} \mathrm{dL}^{-1}$, was determined according to Drabkin (1948); and the red blood cell number, in $10^{6} \mathrm{~mm}^{-3}$, was counted in a Neubauer chamber. From these primary data, the following secondary Wintrobe indices were obtained: mean corpuscular volume, in $\mu \mathrm{m}^{3}$; mean corpuscular hemoglobin, in pg per cell; and mean corpuscular hemoglobin concentration, in percentage.

Plasma samples were deproteinized in $20 \%$ trichloroacetic acid (TCA) to maintain the 1:10 (plasma:TCA) ratio. Fish liver, and red and white muscles were unfrozen, sliced, weighed, and transferred to assay tubes with $20 \%$ TCA to obtain a tissue:TCA ratio of 1:10. Tissues were homogenized with a motor-driven Teflon pestle (model T 10 basic Ultra-Turrax, IKA Brasil, Campinas, SP, Brazil), with two strokes of $30 \mathrm{~s}$ at $1,000 \mathrm{rpm}$, under ice bath. Afterwards, homogenates were centrifuged at $3,000 \mathrm{~g}$ for $10 \mathrm{~min}$, at $5^{\circ} \mathrm{C}$, in an $5424 \mathrm{R}$ centrifuge (Eppendorf AG, Hamburg, Germany), and supernatants were used as protein-free extracts for the determination of metabolites. Ammonia (Gentzkow \& Masen, 1942), protein (Kruger, 1994), glucose (Dubois et al., 1956), triglycerides, total lipids (Folch et al., 1957), and free fatty acids (FFA) (Novák, 1965) were determined in the TCA extracts. In addition, glycogen was quantified in liver and muscles (Bidinotto et al., 1997). Plasma cortisol concentration was obtained by a specific enzyme-linked-immunosorbent assay (Elisa) using the kit from the Neogen Corporation (Lansing, MI, USA).

The biochemical variables were checked for normal distribution and homogeneity of variance, and, as necessary, arc sine transformations were performed. The two-way analysis of variance was used to compare factors and conditions, followed by Tukey's multiple range test to compare significant differences at 5\% probability. All data were expressed as mean \pm standard deviation $(\mathrm{n}=10)$, and each tank was considered as an experimental unit with ten replicates (fish sampled). The SAS software, version 8.0 (SAS Institute Inc., Cary, NC, USA), was used for the analyses.

\section{Results and Discussion}

Rearing of B. amazonicus under sustained swimming attenuated the stress caused by crowding; however, plasma cortisol was increased in HD even in fish adapted to the exercise (Figure $1 \mathrm{~A}$ ). Therefore, the best response was observed in fish subjected to HD and static water, which showed cortisol levels that surpassed in $11.89 \%$ those of fish under HD and exercise. In fish at ID, either in sustained swimming or static water, plasma cortisol was similar to that of those subjected to HD and exercise, but higher than that of those kept in both swimming conditions at LD.

The management of fish rearing systems by introducing mechanisms to control water speed can increase fish resistance to cope with adverse factors, preserving animal welfare (Palstra et al., 2015). Short-term experiments on crowding have shown the high recovery capacity of $B$. amazonicus after stress during transport (Abreu et al., 2008), indicating the high physiological adaptability of the species to cope with crowding. It is possible that the large number of 

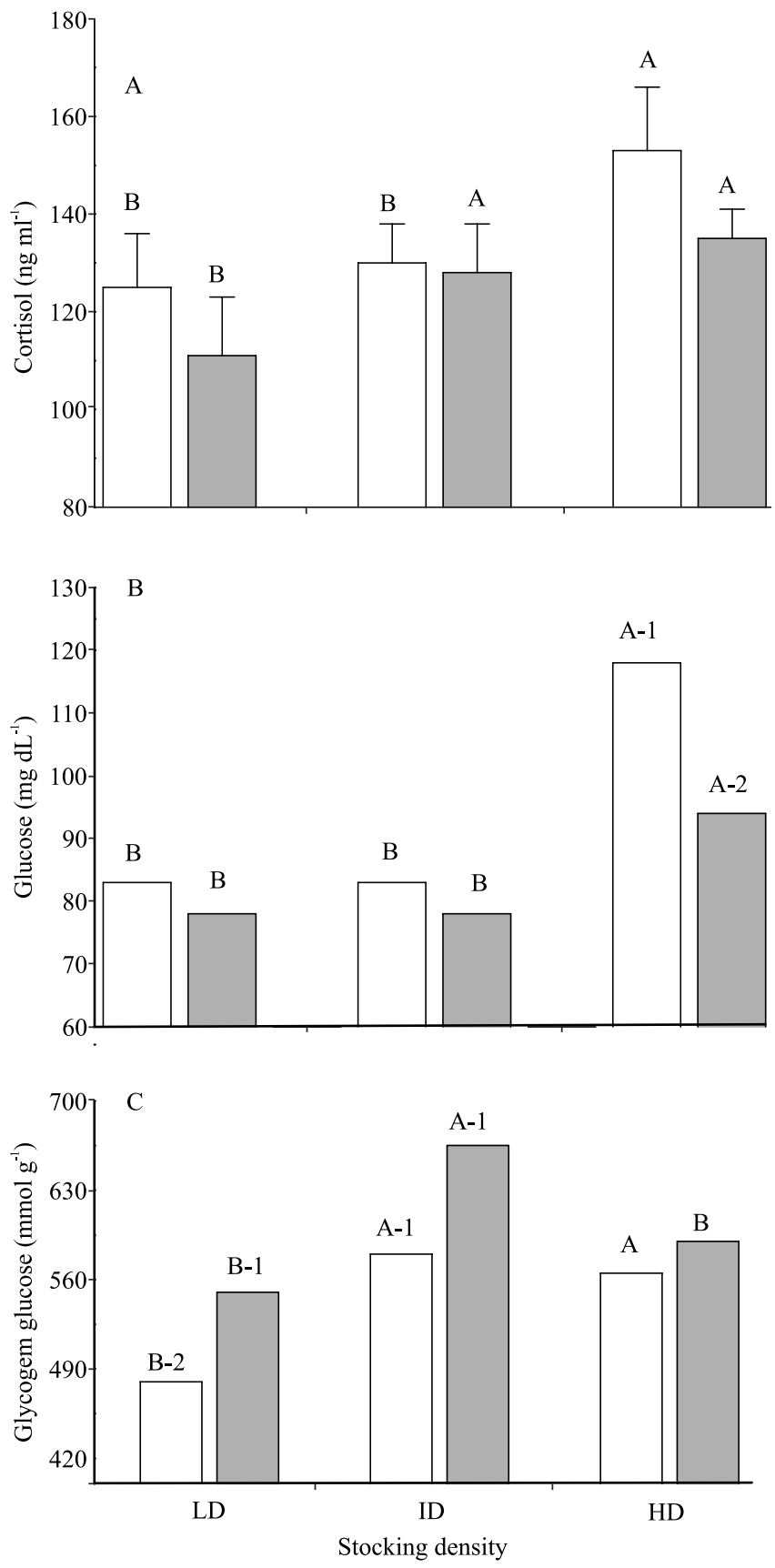

Figure 1. Plasma cortisol (A), glucose (B), and glycogen (C) levels in juvenile Brycon amazonicus subjected to different stocking densities under static water (white bars) or sustained swimming (grey bars). Fish were subjected to three stoking densities for 70 days: LD, low stocking density of 15 fish per tank; ID, intermediary stocking density of 30 fish per tank; and HD, high stocking density of 60 fish per tank. Letters compare stocking densities for the same swimming condition, and numbers compare fish subjected to sustained swimming or to static water in the same stocking density. Values are expressed as mean \pm standard deviation for $n=10$, and differences were significant at $5 \%$ probability. specimens per volume allowed avoiding aggressive interactions, by increasing socialization, as reported for Arctic charr (Salvelinus alpinus) by Jørgensen et al. (1993) and for sea bream (Diplodus sargus) by Papoutsoglou et al. (2006). In addition to high fish densities, moderate exercise also reduces antagonistic behavior and social hierarchy. This fact can be attributed to the modifications in fish behavior when swimming up the stream and grouping into schools, which reduces the stress levels and the number of aggressions (Larsen et al., 2012). Since B. amazonicus is a fish species naturally adapted to continuous swimming over time, it is possible that the exercise contributed to attenuate the chronic stress from high stocking densities.

Regarding cortisol and blood glucose concentrations, a similar trend was verified (Figure 1 B). Plasma glucose levels of non-exercised fish in HD were $20.56 \%$ greater than those of fish subjected to exercise and lower densities. However, the observed values were similar in fish under ID and LD, which were close to those values in fish subjected to exercise. Glucose levels in fish reared in HD were $17 \%$ greater than those of fish kept in LD.

The obtained results show that plasma glucose is a relevant metabolic parameter to indicate changes in homeostasis caused by stressors, as observed in other species (Segner et al., 2012). Augmented plasma glucose, therefore, can be used as a secondary index of stress. In the present study, fish density and exercise were correlated through blood glucose concentration. Stress caused by crowding was exacerbated by nonexercise, but attenuated at low fish densities. The glycemic values of fish under sustained swimming were lower than those of sedentary fish in HD, highlighting the benefic effect of the exercise. Although fish were negatively affected by overcrowding, sustained swimming prevented or reduced the stress caused by $\mathrm{HD}$, as shown by the species physiological profile. It should be noted that free glucose may be originated from distinct metabolic sources but the major supplier is glycogen stored in muscle and liver, which is distributed as glucose to the peripheral tissues (Polakof et al., 2012).

Glycogen bulks in exercised fish (Figure $1 \mathrm{C}$ ) increased $11.41 \%$ in ID, compared with those in HD. However, hepatic glycogen stores in exercised fish under ID were higher than those of every other group, 
reaching values $28 \%$ greater than those of fish kept in LD and in static water. The liver glycogen stores in fish reared under exercise were also increased; however, this raise was more relevant in ID. This result may be explained by the reduction in the energetic expenditure from social antagonistic activities, as also found for rainbow trout (Oncorhynchus mykiss) under low-level sustained exercise (Larsen et al., 2012). In HD, glycogen storage was probably greater due to the decrease of social conflicts (Procarione et al., 1999). Moreover, exercised fish in HD showed cortisol levels lower than those of fish in static water, which is compatible with the increase in liver glycogen. It should be pointed out that high levels of cortisol inhibit liver glycogen stores in fish (Ellis et al., 2012). Therefore, it is possible to presume that the increase of glycogen was a consequence of the cortisol effect, since its multiple physiological actions, including hyperglycemia, are reported to result in peripheral lipolysis and gluconeogenesis from proteolysis, as observed in cortisol implants in common carp (Cyprinus carpio) (Liew et al., 2013).

Protein metabolism can be determined through simple metabolites such as ammonia, FFA, and FAA. Plasma ammonia concentrations increased with stocking density (Table 1), and significant interactions were observed between the studied factors. Fish reared in HD and in static water showed the highest levels of plasma ammonia (Table 2), whereas exercised fish in HD exhibited $33.3 \%$ less ammonia than those kept in static water. In fish reared in LD, the exercise did not affect the plasma levels of ammonia, which were similar to those levels observed in exercised fish subjected to HD (Table 2). Hepatic FFA increased with crowding in all groups, especially in exercised fish, which had the tendency of showing the greatest concentrations. However, no interactions were found between exercise and stocking densities for the hepatic levels of ammonia and FFA, despite being verified for FAA in the liver. The fish subjected to HD, with or without exercise, showed the highest hepatic FAA levels, whereas those in LD presented lower liver FAA mobilization. In this case, crowding contributed to enhancing amino acid mobilization in the liver; however, in exercised fish, this response was only found in HD. In addition, a distinct relationship was observed between the plasma protein profile of exercised and non-exercised fish: the plasma protein levels increased gradually from LD to
ID with exercise, while the greatest values were found in LD and in static water. Still regarding ammonia, its major source is protein catabolism, which is the breakdown of macromolecules. This metabolic feature is usually observed under negative nitrogen balance, which is also suggested by the plasma protein profile, and is considered undesirable because ammonia is toxic and presents many detrimental consequences. However, the basal levels of plasma ammonia were maintained in fish reared under sustained swimming and HD.

When fish are subjected to moderate exercise, a metabolic reorganization occurs and protein is spared. For gilthead sea bream (Sparus aurata), Felip et al. (2013) reported a higher nutrient turnover with exercise and a greater retention of dietary protein, i.e., a higher ${ }^{15} \mathrm{~N}$ uptake into white muscle in the post-prandial period, in response to the stimulus of sustained exercise. In the present study, similar hepatic amino acid profiles were obtained for all evaluated fish densities, combined or not with exercise, suggesting that no damages occurred in the liver of B. amazonicus. Furthermore, no changes were observed in hepatic ammonia. These results suggest that the catabolism of protein, assumed from plasma ammonia, is derived from other tissues rather than the liver and should drive amino acids to hepatic gluconeogenesis, as observed in greater stocking densities.

The levels of plasma triglycerides were affected by fish density: the highest and lowest ones were found in fish reared in HD and in LD, respectively, with or without exercise (Table 2). However, these levels were not affected by crowding in exercised fish, although, in non-exercised ones, there was an increase with the fish population. The content of triglycerides also differed between white and red muscle, since it was affected by exercise and crowding only in the first one. The greatest contents of triglycerides in white muscle were observed in exercised fished reared in LD and ID; however, those under HD presented a decrease in the lesions associated with triglycerides.

Triglycerides are important energetic stores for aerobic exercise, as reported for rainbow trout (Rasmussen et al., 2011). These molecules seem to be mobilized as the energetic demand is increased, as has been found in fish under stress due to confinement at high densities, dietary regimen changes, and the increase of physical activities (McKenzie et al., 2012). 
This mobilization of triglycerides means a decrease of their concentration towards hydrolysis.

Lipid stores in muscles of $B$. amazonicus were mobilized as a function of sustained swimming and fish density. In exercised fish, the deposition of triglycerides in white muscle was stimulated in LD and ID, but decreased in HD, suggesting distinct demands by lipids. This should explain why fish under HD presented lower body mass. A similar response was reported for rainbow trout (McKenzie et al., 2012). Despite these results, some situations demand more interest by low fat fish, with a better fatty acid profile (Rasmussen et al., 2011). This shows the importance of combining fish density and exercise, considering that the benefits from exercise can be blurred by overcrowding stress.

Triglycerides in red muscle did not change in any experimental condition. Although no interaction was observed between exercise and density for lesions associated with triglycerides in red muscle, these values were twofold those found in white muscle in every studied condition. Even though the metabolic rates in red muscle were higher than those in white muscle, the intensiveness of the experimental conditions were likely not enough to lead to significant changes in B. amazonicus. This may be attributed to the fact that, in this species, energetic stores are mobilized for seasonal changes in feeding (Urbinati et al., 2014). The

Table 1. Comparisons of the physiological and metabolic parameters of Brycon amazonicus subjected to different stocking densities, combined with static water (SW) or sustained swimming (SS), for 70 days.

\begin{tabular}{|c|c|c|c|c|c|c|c|c|}
\hline \multirow[t]{3}{*}{ Parameter $^{(1)}$} & \multirow{2}{*}{\multicolumn{3}{|c|}{ P-value ${ }^{(2)}$}} & \multicolumn{5}{|c|}{ Main effect } \\
\hline & & & & \multicolumn{2}{|c|}{ Exercise (condition) } & \multicolumn{3}{|c|}{ Density (factor) ${ }^{(3)}$} \\
\hline & Exercise & Density & Interaction & SW & $\mathrm{SS}$ & LD & ID & HD \\
\hline \multicolumn{9}{|l|}{ Plasma } \\
\hline Ammonia $\left(\mu \mathrm{mol} \mathrm{L}^{-1}\right)$ & 0.001 & 0.074 & 0.001 & $0.59 \pm 0.13$ & $0.51 \pm 0.09$ & $0.55 \pm 0.10$ & $0.51 \pm 0.08$ & $0.59 \pm 0.16$ \\
\hline Protein $\left(\mathrm{g} \mathrm{mL}^{-1}\right)$ & 0.001 & 0.001 & 0.001 & $22.13 \pm 6.50$ & $33.35 \pm 4.53$ & $30.10 \pm 3.56$ & $28.63 \pm 7.01$ & $24.50 \pm 10.75$ \\
\hline $\mathrm{TG}\left(\mathrm{mg} \mathrm{mL} \mathrm{m}^{-1}\right)$ & 0.400 & 0.001 & 0.001 & $522.82 \pm 18.94$ & $524.98 \pm 13.14$ & $509.64 \pm 12.31$ & $525.43 \pm 10.86$ & $537.26 \pm 12.09$ \\
\hline Glucose $\left(\mathrm{mg} \mathrm{dL}^{-1}\right)$ & 0.001 & 0.001 & 0.001 & $95.21 \pm 18.80$ & $83.97 \pm 11.33$ & $81.22 \pm 9.53$ & $81.11 \pm 9.23$ & $106.44 \pm 14.54$ \\
\hline Cortisol (ng mL $\left.L^{-1}\right)$ & 0.001 & 0.001 & 0.036 & $136.47 \pm 17.26$ & $125.01 \pm 15.54$ & $118.17 \pm 14.17$ & $129.53 \pm 11.28$ & $144.53 \pm 15.19$ \\
\hline \multicolumn{9}{|l|}{ Liver } \\
\hline Ammonia $\left(\mu \mathrm{mol} \mathrm{L}{ }^{-1}\right)$ & 0.001 & 0.001 & 0.326 & $57.99 \pm 8.84$ & $65.54 \pm 10.56$ & $61.49 \pm 9.19$ & $56.01 \pm 8.90$ & $67.78 \pm 9.90$ \\
\hline FAA $\left(\mathrm{mg} \mathrm{dL}^{-1}\right)$ & 0.001 & 0.078 & 0.012 & $31.36 \pm 3.45$ & $30.29 \pm 4.98$ & $27.45 \pm 2.68$ & $29.42 \pm 2.58$ & $35.61 \pm 2.24$ \\
\hline FFA $\left(\mathrm{mg} \mathrm{L}^{-1}\right)$ & 0.001 & 0.001 & 0.816 & $64.48 \pm 8.94$ & $77.43 \pm 8.23$ & $64.60 \pm 9.42$ & $70.57 \pm 9.42$ & $77.69 \pm 9.49$ \\
\hline Glycogen & 0.001 & 0.001 & 0.007 & $543.42 \pm 55.07$ & $599.90 \pm 51.68$ & $515.81 \pm 46.48$ & $620.03 \pm 48.26$ & $579.64 \pm 30.48$ \\
\hline \multicolumn{9}{|l|}{ White muscle } \\
\hline $\mathrm{TG}\left(\mathrm{mg} \mathrm{mL}^{-1}\right)$ & 0.348 & 0.001 & 0.001 & $2.78 \pm 0.39$ & $2.86 \pm 0.72$ & $3.22 \pm 0.41$ & $2.79 \pm 0.47$ & $2.45 \pm 0.59$ \\
\hline \multicolumn{9}{|l|}{ Red muscle } \\
\hline $\mathrm{TG}\left(\mathrm{mg} \mathrm{mL}^{-1}\right)$ & 0.001 & 0.001 & 0.063 & $6.12 \pm 0.70$ & $6.56 \pm 0.65$ & $6.93 \pm 0.51$ & $6.35 \pm 0.62$ & $5.72 \pm 0.36$ \\
\hline \multicolumn{9}{|l|}{ Hematology } \\
\hline $\mathrm{Hb}\left(\mathrm{g} \mathrm{dL}^{-1}\right)$ & 0.001 & 0.027 & 0.869 & $9.06 \pm 0.69$ & $9.76 \pm 0.58$ & $9.48 \pm 0.71$ & $9.64 \pm 0.70$ & $9.11 \pm 0.69$ \\
\hline Ht $(\%)$ & 0.688 & 0.324 & 0.601 & $37 \pm 4.53$ & $39.05 \pm 4.73$ & $37.7 \pm 5.47$ & $37.51 \pm 4.35$ & $38.87 \pm 4.34$ \\
\hline $\mathrm{RBC}$ & 0.060 & 0.436 & 0.740 & $2.30 \pm 0.22$ & $2.52 \pm 0.27$ & $2.40 \pm 0.32$ & $2.47 \pm 0.28$ & $2.35 \pm 0.19$ \\
\hline $\operatorname{MCV}\left(\mu \mathrm{m}^{-3}\right)$ & 0.214 & 0.159 & 0.580 & $163.09 \pm 24.47$ & $155.36 \pm 23.57$ & $166.09 \pm 21.84$ & $151.55 \pm 22.67$ & $159.92 \pm 26.55$ \\
\hline $\mathrm{MCH}$ (pg per cell) & 0.198 & 0.666 & 0.565 & $40.98 \pm 5.68$ & $38.82 \pm 6.90$ & $40.90 \pm 8.78$ & $39.70 \pm 4.22$ & $39.09 \pm 5.38$ \\
\hline $\mathrm{MCHC}(\%)$ & 0.036 & 0.889 & 0.064 & $25.38 \pm 3.17$ & $25.26 \pm 4.18$ & $23.71 \pm 3.21$ & $26.53 \pm 3.43$ & $25.72 \pm 3.94$ \\
\hline \multicolumn{9}{|l|}{ Somatic index } \\
\hline HSI & 0.002 & 0.008 & 0.201 & $1.44 \pm 0.15$ & $1.56 \pm 0.15$ & $1.58 \pm 0.14$ & $1.48 \pm 0.17$ & $1.44 \pm 0.14$ \\
\hline $\mathrm{K}$ & 0.016 & 0.271 & 0.526 & $0.96 \pm 0.05$ & $1.02 \pm 0.06$ & $0.98 \pm 0.05$ & $1.02 \pm 0.07$ & $0.98 \pm 0.05$ \\
\hline
\end{tabular}

(1)Parameters were compared by the two-way analysis of variance. TG, triglycerides; FAA, free amino acids; FFA, free fatty acids; Hb, hemoglobin; Ht, hematocrit; RBC, red blood cell count; MCV, mean corpuscular volume; $\mathrm{MCH}$, mean corpuscular hemoglobin; MCHC, mean corpuscular hemoglobin concentration; HSI, hepatosomatic index; and K, condition factor. ${ }^{(2)} \mathrm{P}$-value significant at $<0.05 .{ }^{(3)} \mathrm{LD}$, low stocking density of 15 fish per tank; ID, intermediary stocking density of 30 fish per tank; and HD, high stocking density of 60 fish per tank. 
evaluated conditions, however, changed the plasma levels of triglycerides and ammonia. The higher levels of triglycerides in fish subjected to HD and ID, combined with exercise, indicated a greater metabolic demand in these conditions, which should be a favorable effect for B. amazonicus under exercise. However, opposite responses have been reported for other species, in which high stocking densities reduce triglycerides to counterbalance high metabolic demands (Papoutsoglou et al., 2006). In addition, the metabolic responses imply that lipids in B. amazonicus are likely a key-fuel for fish reared under sustained swimming.

Stocking density or exercise did not interact regarding hematological parameters (Table 1). Hemoglobin, hematocrit, and red blood cell counts presented a discreet increase in response to exercise for all stocking densities; however, this was just a trend and no significant differences were observed. The hematic profile of $B$. amazonicus suggests that overcrowding and sustained swimming can be associated when the species is farmed without apparent adverse consequences.

The HIS and $\mathrm{K}$ did not change either with stocking density or exercise; consequently, no significant interaction was observed between these factors and the assessed conditions (Table 1). However, the increase in fish density reduced the HSI, whereas exercised fish showed greater indices.

Juvenile B. amazonicus subjected to ID and exercise presented the greatest $\mathrm{K}$ indices, suggesting that moderate exercise enhances fish welfare. This index was greater in all fish subjected to exercise, independently of the stocking density, probably because sedentary fish under high densities spend more energy to cope with crowding stress. The combined effects of water quality and high stocking densities also reduced the values of the $\mathrm{K}$ of rainbow trout due to low water quality and feeding conditions, causing alterations to fish welfare (Person-Le Ruyet et al., 2008). In the present study, the sharing of the food pellets and the water quality were improved, and the aggressive behavior was reduced, sparing energy for the anabolic processes. This may explain the increase in the $\mathrm{K}$ in $B$. amazonicus. The obtained results show that sustained swimming is a recommended strategy to enhance the growth rates and life quality of B. amazonicus, particularly in intensive fish culture systems.

Table 2. Metabolic performance of Brycon amazonicus subjected to different stocking densities, combined with static water (SW) or sustained swimming (SS), for 70 days ${ }^{(1)}$.

\begin{tabular}{|c|c|c|c|c|c|c|c|}
\hline \multirow[t]{2}{*}{ Parameter } & \multicolumn{2}{|c|}{ LD } & \multicolumn{2}{|c|}{ ID } & \multicolumn{2}{|c|}{ HD } & \multirow[t]{2}{*}{ P-value } \\
\hline & SW & SS & SW & SS & SW & SS & \\
\hline \multicolumn{8}{|l|}{ Plasma } \\
\hline Ammonia $\left(\mu \mathrm{mol} \mathrm{L}^{-1}\right)$ & $0.53 \pm 0.09$ & $0.57 \pm 0.10$ & $0.55 \pm 0.07$ & $0.47 \pm 0.07$ & $0.69 \pm 0.16 \mathrm{a}$ & $0.48 \pm 0.05 b$ & 0.001 \\
\hline Protein $\left(\mathrm{g} \mathrm{mL}^{-1}\right)$ & $29.2 \pm 3.82$ & $31.0 \pm 3.23$ & $22.2 \pm 1.64 \mathrm{~b}$ & $35.0 \pm 3.07 \mathrm{a}$ & $15.0 \pm 2.65 b$ & $34.0 \pm 6.03 \mathrm{a}$ & 0.001 \\
\hline $\mathrm{TG}(\mathrm{mg} \mathrm{mL}-1)$ & $503.5 \pm 10.3$ & $515.8 \pm 11.40$ & $524.5 \pm 12.2$ & $526.5 \pm 9.76$ & $540.5 \pm 11.6$ & $533.7 \pm 12.19$ & - \\
\hline \multicolumn{8}{|l|}{ Liver } \\
\hline Ammonia $\left(\mu \mathrm{mol} \mathrm{L}^{-1}\right)$ & $56.73 \pm 7.04$ & $66.27 \pm 8.85$ & $54.59 \pm 8.38$ & $57.44 \pm 9.61$ & $62.65 \pm 9.68$ & $72.92 \pm 7.40$ & - \\
\hline FAA $\left(m g ~ d L^{-1}\right)$ & $28.49 \pm 2.32$ & $26.42 \pm 2.7$ & $30.75 \pm 2.10$ & $28.08 \pm 2.38$ & $34.85 \pm 2.34$ & $36.38 \pm 1.97$ & - \\
\hline FFA $\left(\mathrm{mg} \mathrm{L}^{-1}\right)$ & $57.91 \pm 6.89$ & $71.29 \pm 6.37$ & $64.88 \pm 8.68$ & $76.27 \pm 6.31$ & $70.66 \pm 6.67$ & $84.73 \pm 5.97$ & - \\
\hline \multicolumn{8}{|l|}{ White muscle } \\
\hline $\mathrm{TG}\left(\mathrm{mg} \mathrm{mL}^{-1}\right)$ & $3.03 \pm 0.37$ & $3.41 \pm 0.36$ & $2.39 \pm 0.24 \mathrm{~b}$ & $3.20 \pm 0.21 \mathrm{a}$ & $2.94 \pm 0.22 \mathrm{a}$ & $1.97 \pm 0.43 \mathrm{~b}$ & 0.001 \\
\hline \multicolumn{8}{|l|}{ Red muscle } \\
\hline $\mathrm{TG}\left(\mathrm{mg} \mathrm{mL}^{-1}\right)$ & $6.86 \pm 0.50$ & $7.00 \pm 0.54$ & $5.95 \pm 0.44$ & $6.76 \pm 0.50$ & $5.58 \pm 0.32$ & $5.90 \pm 0.3$ & - \\
\hline \multicolumn{8}{|l|}{ Somatic index } \\
\hline HSI & $1.50 \pm 0.14$ & $1.67 \pm 0.11$ & $1.40 \pm 0.16$ & $1.57 \pm 0.14$ & $1.43 \pm 0.15$ & $1.46 \pm 0.13$ & - \\
\hline $\mathrm{K}$ & $0.96 \pm 0.05$ & $1.01 \pm 0.05$ & $0.97 \pm 0.06$ & $1.08 \pm 0.06$ & $0.96 \pm 0.05$ & $1.00 \pm 0.05$ & - \\
\hline
\end{tabular}




\section{Conclusion}

Juvenile Brycon amazonicus is more resistant to stress when subjected to sustained swimming and high stocking densities than when subjected to static water, showing a decrease in plasma cortisol levels, as well as an increase in plasma glucose, in hepatic glycogen stores, and in muscle triglycerides.

\section{Acknowledgments}

To Conselho Nacional de Desenvolvimento Científico e Tecnológico (CNPq) and to Fundação de Amparo à Pesquisa do Estado de São Paulo (Fapesp), for financial support; and to the colleagues of the laboratory of adaptive biochemistry of fish of Universidade Federal de São Carlos, for support.

\section{References}

ABREU, J.S. de; SANABRIA-OCHOA, A.I.; GONÇALVES, F.D.; URBINATI, E.C. Stress responses of juvenile matrinxã (Brycon amazonicus) after transport in a closed system under different loading densities. Ciência Rural, v.38, p.1413-1417, 2008. DOI: $10.1590 /$ S0103-84782008000500034.

ARBELÁEZ-ROJAS, G.; MORAES, G. Optimization of sustaining swimming speed of matrinxã Brycon amazonicus: performance and adaptive aspects. Scientia Agricola, v.67, p.253258, 2010. DOI: 10.1590/S0103-90162010000300001.

ASHLEY, P.J. Fish welfare: current issue in aquaculture. Applied Animal Behavior Science, v.104, p.199-235, 2007. DOI: 10.1016/j. applanim.2006.09.001.

BADIOLA, M.; MENDIOLA, D.; BOSTOCK, J. Recirculating Aquaculture Systems (RAS) analysis: main issues on management and future challenges. Aquacultural Engineering, v.51, p.26-35, 2012. DOI: $10.1016 /$ j.aquaeng.2012.07.004.

BIDINOTTO, P.M.; MORAES, G.; SOUZA, R.H.S. Hepatic glycogen in eight tropical fresh water teleost fish: a procedure for field determinations of micro samples. Boletim Técnico do CEPTA, v.10, p.53-60, 1997.

BJÖRNSSON, B.; ÓLAFSDÓTTIR, S.R. Effects of water quality and stocking density on growth performance of juvenile cod (Gadus morhua L.). ICES Journal of Marine Science, v.63, p.326-334, 2006. DOI: 10.1016/j.icesjms.2005.10.010.

CRUZ-CASALLAS, P.B.; MEDINA-ROBLES, V.M.; VELASCOSANTAMARÍA, Y.M. Fish farming of native species in Colombia: current situation and perspectives. Aquaculture Research, v.42, p.823-831, 2011. DOI: 10.1111/j.1365-2109.2011.02855.x.

DAVISON, W.; HERBERT, N.A. Swimming-enhanced growth. In: PALSTRA, A.P.; PLANAS, J.V. (Ed). Swimming physiology of fish: towards using exercise to farm a fit fish in sustainable aquaculture. Berlin: Springer, 2013. p.177-202. DOI: 10.1007/9783-642-31049-2_8.
DRABKIN, D.L. The standardization of hemoglobin measurement. The American Journal of the Medical Sciences, v.215, p.110-111, 1948. DOI: 10.1097/00000441-194801000-00017.

DUBOIS, M.; GILLES, K.A.; HAMILTON, J.K.; REBERS, P.A.; SMITH, F. Colorimetric method for determination of sugars and related substances. Analytical Chemistry, v.28, p.350-356, 1956. DOI: $10.1021 / \mathrm{ac} 60111 \mathrm{a} 017$.

ELLIS, T.; YILDIZ, H.Y.; LÓPEZ-OLMEDA, J.; SPEDICATO, M.T.; TORT, L.; ØVERLI, Ø.; MARTINS, C.I.M. Cortisol and finfish welfare. Fish Physiology and Biochemistry, v.38, p.163188, 2012. DOI: 10.1007/s10695-011-9568-y.

FAO. Food and Agriculture Organization of the United Nations. The state of world fisheries and aquaculture 2016: contributing to food security and nutrition for all. Rome, 2016. 200p.

FAZIO, F.; FAGGIO, C.; PICCIONE, G.; BONFIGLIO, R.; MARINO, F. Effect of rearing density on the blood and tissues of mullet (Mugil cephalus L.). Marine and Freshwater Behaviour and Physiology, v.47, p.389-399, 2014. DOI: 10.1080/10236244.2014.955351.

FELIP, O.; BLASCO, J.; IBARZ, A.; MARTIN-PEREZ, M.; FERNÁNDEZ-BORRÀS, J. Beneficial effects of sustained activity on the use of dietary protein and carbohydrate traced with stable isotopes ${ }^{15} \mathrm{~N}$ and ${ }^{13} \mathrm{C}$ in gilthead sea bream (Sparus aurata). Journal of Comparative Physiology B, v.183, p.223-234, 2013. DOI: $10.1007 / \mathrm{s} 00360-012-0703-6$.

FOLCH, J.; LESS, M.; STANLEY, H.S. A simple method for the isolation and purification of total lipides from animal tissues. The Journal of Biological Chemistry, v.226, p.497-509, 1957.

GENTZKOW, C.J.; MASEN, J.M. An accurate method for the determination of blood urea nitrogen by direct nesslerization. The Journal of Biological Chemistry, v.143, p.531-544, 1942.

JØRGENSEN, E.H.; CHRISTIANSEN，J.S.; JOBLING， M. Effects of stocking density on food intake, growth performance and oxygen consumption in Arctic charr (Salvelinus alpinus). Aquaculture, v.110, p.191-204, 1993. DOI: 10.1016/00448486(93)90272-Z.

KRUGER, N.J. The Bradford method for protein quantification. In: WALKER, J.M. (Ed.). Basic protein and peptide protocols. Totowa: Humana Press, 1994. p.9-15. (Methods in Molecular Biology, v.32).

LARSEN, B.K.; SKOV, P.V.; MCKENZIE, D.J.; JOKUMSEN, A. The effects of stocking density and low level sustained exercise on the energetic efficiency of rainbow trout (Oncorhynchus mykiss) reared at $19^{\circ} \mathrm{C}$. Aquaculture, v.324-325, p.226-233, 2012. DOI: 10.1016/j.aquaculture.2011.10.021.

LIEW, H.J.; CHIARELLA, D.; PELLE, A.; FAGGIO, C.; BLUST, R.; DE BOECK, G. Cortisol emphasizes the metabolic strategies employed by common carp, Cyprinus carpio at different feeding and swimming regimes. Comparative Biochemistry and Physiology. Part A: Molecular and Integrative Physiology, v.166, p.449-464, 2013. DOI: 10.1016/j.cbpa.2013.07.029.

MCKENZIE, D.J.; HÖGLUND, E.; DUPONT-PRINET, A.; LARSEN, B.K.; SKOV, P.V.; PEDERSEN, P.B.; JOKUMSEN, A. Effects of stocking density and sustained aerobic 
exercise on growth, energetics and welfare of rainbow trout. Aquaculture, v.338-341, p.216-222, 2012. DOI: 10.1016/j. aquaculture.2012.01.020.

NOVÁK, M. Colorimetric ultramicro method for the determination of free fatty acids. Journal of Lipid Research, v.6, p.431-433, 1965 .

PALSTRA, A.P.; MES, D.; KUSTERS, K.; ROQUES, J.A.C.; FLIK, G.; KLOET, K.; BLONK, R.J.W. Forced sustained swimming exercise at optimal speed enhances growth of juvenile yellowtail kingfish (Seriola lalandi). Frontiers in Physiology, v.5, article 506, 2015. DOI: 10.3389/fphys.2014.00506.

PAPOUTSOGLOU, S.E.; KARAKATSOULI, N.; PIZZONIA, G.; DALLA, C.; POLISSIDIS, A.; PAPADOPOULOU-DAIFOTI, $Z$. Effects of rearing density on growth, brain neurotransmitters and liver fatty acid composition of juvenile white sea bream Diplodus sargus L. Aquaculture Research, v.37, p.87-95, 2006. DOI: 10.1111/j.1365-2109.2005.01401.x.

PERSON-LE RUYET, J.; LABBE, L.; LE BAYON, N.; SÉVÈRE, A.; LE ROUX, A.; LE DELLIOU, H.; QUÉMÉNER, L. Combined effects of water quality and stocking density on welfare and growth of rainbow trout (Oncorhynchus mykiss). Aquatic Living Resources, v.21, p.185-195, 2008. DOI: 10.1051/alr:2008024.

POLAKOF, S.; PANSERAT, S.; SOENGAS, J.L.; MOON, T.W. Glucose metabolism in fish: a review. Journal of Comparative Physiology B, v.182, p.1015-1045, 2012. DOI: 10.1007/s00360012-0658-7.
PROCARIONE, L.S.; BARRY, T.P.; MALISON, J.A. Effects of high rearing densities and loading rates on the growth and stress responses of juvenile rainbow trout. North American Journal of Aquaculture, v.61, p.91-96, 1999. DOI: 10.1577/1548-8454(1999)061<0091:EOHRDA>2.0.CO;2.

RASMUSSEN, R.S.; HEINRICH, M.T.; HYLDIG, G.; JACOBSEN, C.; JOKUMSEN, A. Moderate exercise of rainbow trout induces only minor differences in fatty acid profile, texture, white muscle fibres and proximate chemical composition of fillets. Aquaculture, v.314, p.159-164, 2011. DOI: 10.1016/j. aquaculture.2011.02.003.

SEGNER, H.; SUNDH, H.; BUCHMANN, K.; DOUXFILS, J.; SUNDELL, K.S.; MATHIEU, C.; RUANE, N.; JUTFELT, F.; TOFTEN, H.; VAUGHAN, L. Health of farmed fish: its relation to fish welfare and its utility as welfare indicator. Fish Physiology and Biochemistry, v.38, p.85-105, 2012. DOI: 10.1007/s10695011-9517-9.

URBINATI, E.C.; SARMIENTO, S.J.; TAKAHASHI, L.S. Short-term cycles of feed deprivation and refeeding promote full compensatory growth in the Amazon fish matrinxã (Brycon amazonicus). Aquaculture, v.433, p.430-433, 2014. DOI: 10.1016/j.aquaculture.2014.06.030.

VEISETH, E.; FJAERA, S.O.; BJERKENG, B.; SKJERVOLD, P.O. Accelerated recovery of Atlantic salmon (Salmo salar) from effects of crowding by swimming. Comparative Biochemistry and Physiology. Part B: Biochemistry and Molecular Biology, v.144, p.351-358, 2006. DOI: 10.1016/j.cbpb.2006.03.009.

Received on July 14, 2016 and accepted on November 9, 2016

Pesq. agropec. bras., Brasília, v.52, n.1, p.1-9, jan. 2017 DOI: 10.1590/S0100-204X2017000100001 